\title{
PREVALENCE AND RISK FACTORS OF HYPERTENSION AMONG ADOLESCENTS AGED 18 to 21 YEARS IN INDONESIA
}

\author{
Lydia Gresari Br Sembiring, Diah Mulyawati Utari
}

Masters Program of Public Health, Faculty of Public Health, Universitas Indonesia

\begin{abstract}
Background: Hypertension is a major risk factor for cardiovascular diseases and other complications. There are several factors predisposing to hypertension. These factors vary from country to country and there is difference between urban and rural region. This study aimed to determine the prevalence and risk factors of hypertension among adolescents aged 18 to 21 years in Indonesia.

Subjects and Method: This was a cross sectional study using IFLS 5 data year 2014. A total of 2,531 adolescents aged 18 to 21 years were selected for this study. The dependent variable was hypertension. The independent variables were age, sex, body mass index (BMI), psychological condition, healthy food, physical activity, smoking habit, and residential area. The data were obtained from Indonesian Family Life Survey 5 (IFLS 5) year 2014. The data were analyzed by a multiple logistic regression.

Results: As many as 39.8\% adolescents aged 18 to 21 years had pre-hypertension and $6.2 \%$ had hypertension. The risk of hypertension increased with male $(\mathrm{aOR}=2.40 ; 95 \% \mathrm{CI}=1.98$ to 2.96 ; $\mathrm{p}=0.001)$, high $\mathrm{BMI} \geq 25 \mathrm{kgBW} / \mathrm{m}^{2} \mathrm{BH}(\mathrm{aOR}=3.85 ; 95 \% \mathrm{CI}=1.82$ to $8.12 ; \mathrm{p}=0.001)$, poor psychological condition $(\mathrm{aOR}=1.47 ; 95 \% \mathrm{CI}=1.47$ to $2.11 ; \mathrm{p}=0.030)$, and unhealthy food $(\mathrm{aOR}=1.34 ; 95 \% \mathrm{CI}=1.18$ to 2.33; $\mathrm{p}=0.004)$.
\end{abstract}

Conclusion: The risk of hypertension increases with male, BMI $\geq 25 \mathrm{kgBW} / \mathrm{m}^{2} \mathrm{BH}$, poor psychological condition, and unhealthy food.

Keywords: hypertension, BMI, psychological condition, healthy food, adolescents.

\section{Correspondence:}

Lydia Gresari Br Sembiring. Masters Program in Public Health, Faculty of Public Health, Universitas Indonesia, Depok, West Java. Email: lidya.gresari@gmail.com. Mobile: 0811603823.

\section{BACKGROUND}

Hypertension is a global problem that is related to systolic blood pressure $\geq 140 \mathrm{mmHg}$ and or diastolic blood pressure $\geq 90 \mathrm{mmHg}$. Hypertension is a major risk factor for cardiovascular disease and other complications associated with increased morbidity, global mortality and health costs. Globally, hypertension accounts for 7.5 million deaths per year and is at risk of heart disease, $51 \%$ of deaths due to stroke and triggers for kidney disorders (WHO, 2013).

Based on BPJS report on 2015, the burden of health costs that must be borne by the government from hospitalization at around 363 billion hospitals to pay for 95,087 cases of essential hypertension referred to the hospital, with a case-handling fee of $\mathrm{Rp}$ $3,821,301$.

The problem of hypertension every year cannot be resolved even tends to increase. Based on the results of Basic Health Research data on 2017, the prevalence of hypertension in Indonesia reached $31.7 \%$, in 2013 it fell to 25.8\%, and in 2018 it increased again to 34.1\% (Ministry of Health, 2007).

Hypertension can also be experienced by children and adolescents. Hypertension cases found around $0.7 \%$ per year in children and $0.3 \%$ per year in adolescents. It is followed by an increase in cases of pre hypertension in adolescents $1.1 \%$ at initial screening (Falkner, 2011). A study conducted in the United States found that 2.7\% of children aged 10-19 years had hypertension 
and $16.3 \%$ included in the category of prehypertension (Cheung et al., 2017).

Hypertension experienced by adolescents associated with multifactorial that cannot be ascertained as a single cause. Blood pressure testing in adolescents is often ignored by governments and health services. Recognizing the risk factors for hypertension accompanied by early detection of hypertension can increase prevention of hypertension and cardiovascular disease in adulthood. This study aims to determine the prevalence and risk factors for hypertension in adolescents aged 18 to 21 years in Indonesia

\section{SUBJECTS AND METHOD}

\section{Design Study}

This was a cross-sectional study design with using secondary data from Indonesia Family Life Survey 5 (IFLS 5) in 2014-2015.

\section{Population and Sample}

The general population in this study was all individuals aged 15 to 21 years as many as 2,582 people. The sample size was calculated according to the hypothesis test formula for two population proportions with a minimum of 722 samples with inclusion criteria of adolescents aged 18-21 years who had complete data for all study variables. Exclusion criteria if a teenager has been diagnosed with hypertension, diabetes mellitus, coronary heart disease, and stroke or kidney failure and was taking anti-hypertension drugs until blood pressure measurements were taken. From the cleaning results obtained 2,531 respondents.

\section{Study Variables}

The independent variable was hypertension which was obtained from blood pressure measurement data when the systolic pressure was $\geq 120 \mathrm{mmHg}$ and/ or diastolic pressure $\geq 8 \mathrm{o} \mathrm{mmHg}$. Measurement of blood pressure that was seen was 2 calculations the difference that was closest to the first measurement. Dependent variables included sex, age, residential area, body mass index, psychological condition, healthy food, physical activity and smoking habit.

\section{Instrument of the Study}

Body Mass Index (BMI) was obtained from the division of body weight $(\mathrm{kg})$ by height squared $(\mathrm{m})$. Then classified as obese (BMI> $27 \mathrm{~kg} / \mathrm{m}^{2}$ ), overweight (BMI $25-27 \mathrm{~kg} / \mathrm{m}^{2}$ ), normal (BMI $18.5-24.9 \mathrm{~kg} / \mathrm{m}^{2}$ ), and thin (BMI $\left.<18.5 \mathrm{~kg} / \mathrm{m}^{2}\right)$. Psychological conditions were obtained from Likert scores on 10 questions referring to the CES-D short questioners. Each question item had 4 answer choices, namely: never ( $<1$ day), rarely (1-2 days), sometimes (3-4 days), and often (5-7 days) (Andersen et al., 1994). If the total score $<10$, it will be classified as no depression.

Food security was obtained from the frequency of food included and food diversity in the analysis of food consumption. Food consumption score (FCS) was produced from the calculation of frequency and weight per food group.

If the total FCS is $<21$ then it is categorized as low, if the total FCS score of 21-35 is categorized as sufficient, then if the food score consumed exceeds 35 then it is categorized as good. Then the FCS category is low and the limit is classified as customerprone, if the FCS category is good then it is not food-prone. Physical activity referred to the use of the IPAQ short questioner, which was converted in units of Met-minutes/ week. If <600 MET-minutes/ week it is categorized as low, if between 600-2999 MET minutes/ week it is categorized as moderate, and if $\geq 3000$ MET-minutes/ week the level of physical activity is categorized as heavy

\section{Data Analysis}

All univariate, bivariate, and multivariate test analyzes were analyzed using SPSS. 


\section{RESULTS}

The general characteristics of the study population are illustrated in Table 1.

Table 1. General characteristics of the study population Variables

\begin{tabular}{lcc}
\hline Variable & Frequency & Percent \\
\hline Ages & 648 & \\
18 & 659 & 25.6 \\
19 & 617 & 24.0 \\
20 & 607 & 24.0 \\
21 & & \\
Sex & 1132 & 44.7 \\
Male & 1139 & $55 \cdot 3$ \\
Female & & \\
Village & 1621 & 64.0 \\
Urban & 910 & 36.0 \\
Rural & & \\
BMI & 580 & 22.9 \\
Underweight & 1597 & 63.1 \\
Normal & 140 & 5.5 \\
Overweight & 214 & 8.5 \\
Obese & & \\
Psychology & 831 & 32.8 \\
Depression & 1700 & 67.2 \\
No &
\end{tabular}

Depression

\section{Food}

\section{Security}

Poor \&

Borderline

Acceptable

Physical

Activity

Low

Medium

High

Smoking

Yes

No

1039

43.7

56.3

1336

(1)

68.5

24.8

6.4

27.5

72.5

Tabel 2. Prevalence of Hypertension

\begin{tabular}{lcc}
\hline \multicolumn{1}{c}{ Variable } & $\mathbf{N}$ & $\mathbf{~ \%}$ \\
\hline Normal & 1,367 & 54 \\
Pre-hypertension & 1,008 & 39.8 \\
Hypertension Stage 1 & 146 & 5.8 \\
Hypertension Stage 2 & 10 & 0.4 \\
\hline
\end{tabular}

Table 3. Bivariate Analysis

\begin{tabular}{|c|c|c|c|c|c|c|c|}
\hline \multirow{3}{*}{ Variables } & \multicolumn{4}{|c|}{ Hypertension } & \multirow{3}{*}{ OR } & \multirow{3}{*}{ 95\% CI } & \multirow{3}{*}{$\mathbf{p}$} \\
\hline & \multicolumn{2}{|c|}{ Yes } & \multicolumn{2}{|c|}{ No } & & & \\
\hline & $\mathbf{n}$ & $\%$ & $\mathbf{n}$ & $\%$ & & & \\
\hline \multicolumn{8}{|l|}{ Region } \\
\hline Urban & 100 & 6.2 & 1521 & 93.8 & 1.00 & $0.72-1.41$ & 1.000 \\
\hline Rural & 56 & 35.9 & 854 & 93.8 & & & \\
\hline
\end{tabular}

Table 3 shows the correlation between sex, BMI, healthy food, and the correlation bet- ween smoking and hypertension in adolescents aged 18-21 years.

Table 4. Results of multiple logistic regression analysis

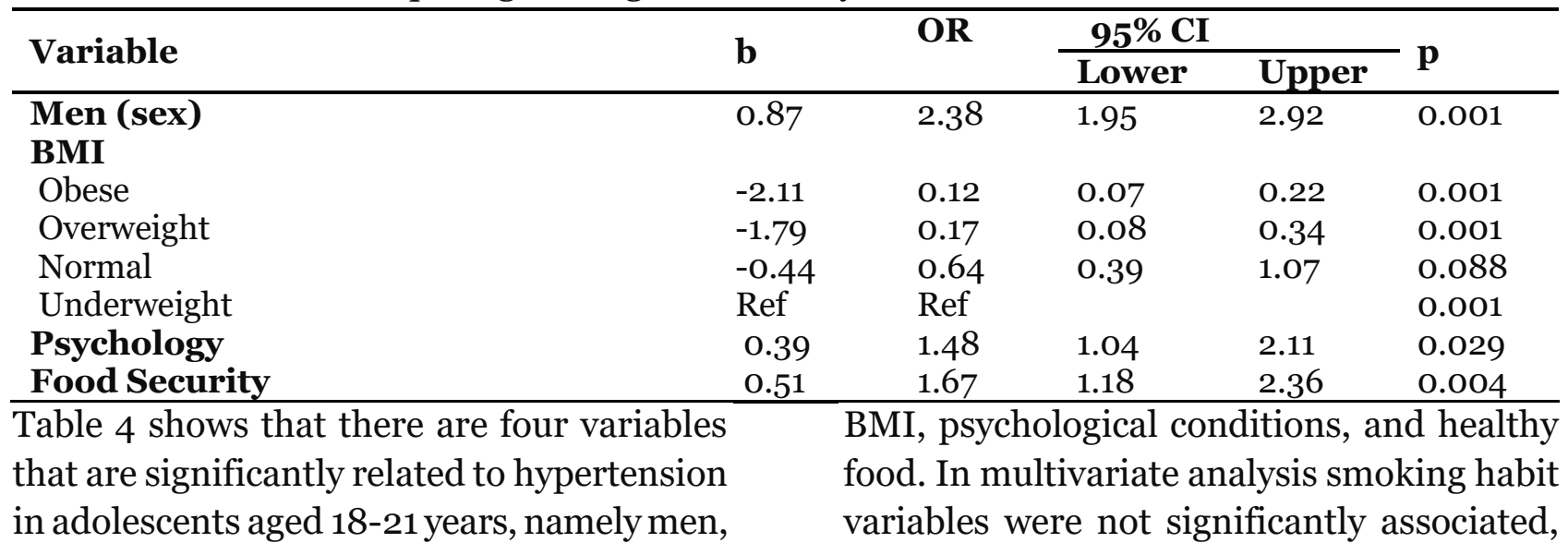


whereas psychological variables were signifycantly associated to hypertension in adolescents. The most dominant variable was men.

\section{DISCUSSION}

This study found that the characteristics of adolescents aged 18-21 years who suffer the most hypertension in Indonesia are men, have a category of body mass index (BMI) obesity, a high level of activity, and domiciled in rural areas. The characteristics of physical activity are almost the same as the characteristics of Dewi's study in 2012 concerning risk factors for hypertension in adolescents aged 15-17 who used Basic Health Research (RISKESDAS) data in 2007 except for physical activity variables. The percentages in the physical activity variable categories are sufficient and less similar.

Knowing the prevalence of hypertension and pr3 hypertension in children can be an alarm in identifying populations at risk. The prevalence of hypertension (6.2\%) in this study is higher when compared with the results of studies in Europe showing the prevalence of hypertension in children and adolescents by $1 \%-4 \%$ (Kollias, 2011).

However, the prevalence of hypertension in this study is lower compared to Basic Health Research study on 2007 (29.7\%) (Dewi, 2012). This is because the age range in the 2007 Basic Health Research study was shorter than 15-17 years.

In this study, between sex and the incidence of hypertension in adolescents in Indonesia showed a meaningful correlation. Male adolescents (10.6\%) had more hypertension compared to female adolescent (2.6\%) who had hypertension. This is in line with a study conducted in Iran, showing the risk that boys are more likely to experience prehypertension and hypertension than girls (Amiri et al., 2019).

Sex is significantly related to hypertension. Men are more at risk 2.3 times than women. The prevalence of hypertension in men when compared to women has a higher average blood pressure than in women of $5.77 \mathrm{mmHg}$ (Yusrizal et al., 2016).

Androgen hormones play an important role in the difference between blood pressure between men and women (Dewi, 2012). Androgen hormones cause an increase in renin-angiotensinogen, renin activity, angiotensin II and affect renal vasoconstriction so that it stimulates sodium reabsorption, until finally an increase in blood pressure (Reckelhoff, 2001).

In this study, between BMI and the incidence of hypertension in adolescents in Indonesia showed a significant correlation. Every increase in BMI is associated with an increased risk of hypertension. This is in line with the average SBP and DBP proven progressively increasing with each BMI category in both sexes and all age groups (Israeli et al., 2006). Every $1 \mathrm{~kg} / \mathrm{m} 2$ increase in BMI will increase blood pressure 4.85 mmHg (Yusrizal et al., 2016).

In this study, between the psychological conditions of depression with the incidence of hypertension in adolescents in Indonesia in the bivariate analysis showed no significant correlation. The difference in the percentage of adolescents who were depressed with hypertension (7.5\%) and nondepressed with hypertension (5.5\%) was not too large, but the psychological variable in the form of depression in multivariate analysis was associated with an increased risk of hypertension.

This is not in line with a study at Andalas Padang Health Center which found an association between depression and blood pressure $(\mathrm{p}=0.020)$ (Darmayanti, 2017).

Stress or depression can result in recurring blood pressure fluctuations and stimulation of the sympathetic nervous system which produces large amounts of hormones that cause vasoconstriction (Peltzer, 
2017). The differences in the results of this study are affected by different categories of respondents from the age range and hypertension status.

In this study, food security with the incidence of hypertension in adolescents in Indonesia has a significant correlation. Food security correlates with food frequency and food diversity. Someone who experiences food insecurity has a risk of 1.66 times compared to adolescents who are not food insecure (95\% CI= 1.18 to 2.36 ).

This is in line with a study in Mississippi, groups that experience high blood pressure have a greater chance of experiencing food insecurity (Mendy et al., 2018). Generalized Estimating Equation (GEE) results between food security and hypertension in Indonesia which show a negative correlation between the dependent variable and independent variables such as the Food Consumption Score (FCS), the Food Consumption Group (FCG), and Food Security (FCG) FS) (p <0.001) (Isaura et al., 2017).

Food security is associated to access to adequate nutritious food to prevent disease. The correlation between food insecurity and hypertension is related to limited socioeconomic access, physiological stress, or excessive consumption of foods that are poor in nutrition and high in sodium (Seligman \& Schillinger, 2010).

The most dominant factors associated with hypertension in late adolescents are sex, food security, psychology, and BMI. Someone who has been diagnosed with hypertension can only control blood pressure and cannot recover completely. Early recognition of risk factors can increase effective prevention due to increased blood pressure. Efforts by the government to improve preventive programs are such as a combination of routine blood pressure monitoring and health education programs related to nutrition education and promotion of balanced nutrition for the com- munity. This should be done in order to reduce and overcome the late adolescent hypertension in Indonesia.

\section{REFERENCES}

Amiri P, Vahedi-Notash GP, Khalili D, Nazar SS, Mehrabi Y, Hazaveh AR (2019). National Trends of Pre-Hypertension and Hypertension among Iranian Adolescents across Urban and Rural Areas, 10(18).

Cheung EL, Bell CS, Samuel JP (2017). Race and Obesity in Adolescent Hypertension. Pediatrics, 139(5)

Damayatri N (2017). Hubungan Depresi dan Dukungan Sosial Dengan Tekanan Darah Pada Pasien Hipertensi di Wilayah Kerja Puskesmas Andalas Kota Padang Tahun 2017. Universitas Andalas.

Dewi RA (2012). Analisis Faktor Risiko Hipertensi Pada Remaja Usia 15-17 Tahun di Indonesia Tahun 2007 (Analisis Data Riskesdas 2007). Universitas Indonesia: Depok.

Falkner B (2011). Prehypertension in Adolescents: How High is the Risk for Hypertension? 160(1): 98.

Isaura ER, Chen YC, Yang SH (2017). The Association of Food Consumption Score, Body Shape Index, and Hypertension in a Seven-Year Follow-Up among Adults: A Longitudinal Study. International Journal of Environmental Research and Public Health, 15 .

Kollias A (2011). Hypertension in Children and Adolescents. Pediatric Clinics of North America. 1(1): 15-19.

Lande MB, Kupferman JC (2019). Hypertension, 73. 532-540.

Enkhmaa B, Zhang L (2018). Food Insecurity and Cardiovascular Disease Risk Factors among Mississippi Adults. Int 
J Environ Res Public Health. 15(9). Doi: 10.3390/ijerph15092016

Peltzer K, Pengpid S (2018). The Prevalence and Social Determinants of Hypertension among Adults in Indonesia: A Cross-Sectional Population-Based National Survey. 4: 1-9

Reckelhoff J (2001). Gender Differences in the Regulation of Blood Pressure. Journal of the American Heart Association, 37: 1199-1208
Santoso D (2013). Prevalensi Hipertensi pada Pelajar dan Mahasiswa. Jurnal Kesehatan Masyarakat Nasional, 7(11).

Seligman HK, Schillinger D (2010). Hunger and Socioeconomic Disparities in Chronic Disease. New England Journal Medicine, 363(1): 6-9

WHO (2013). A global brief on Hypertension. 